\title{
Note on Lepidoptera from Bulgarian Caves
}

\author{
mgr Andrzej W. SKALSKI*
}

The Lepidoptera, which are a typically phytophagous, epigean group of insects, are represented in caves only as trogloxenes and subtroglophiles. However, they merit attention as essential components of the parietal accociation. In recent years Lepidoptera aggregations in caves have been studied only by Kowalski (1965, several species) and Graham (1968, 1968a, Triphosa haesitata).

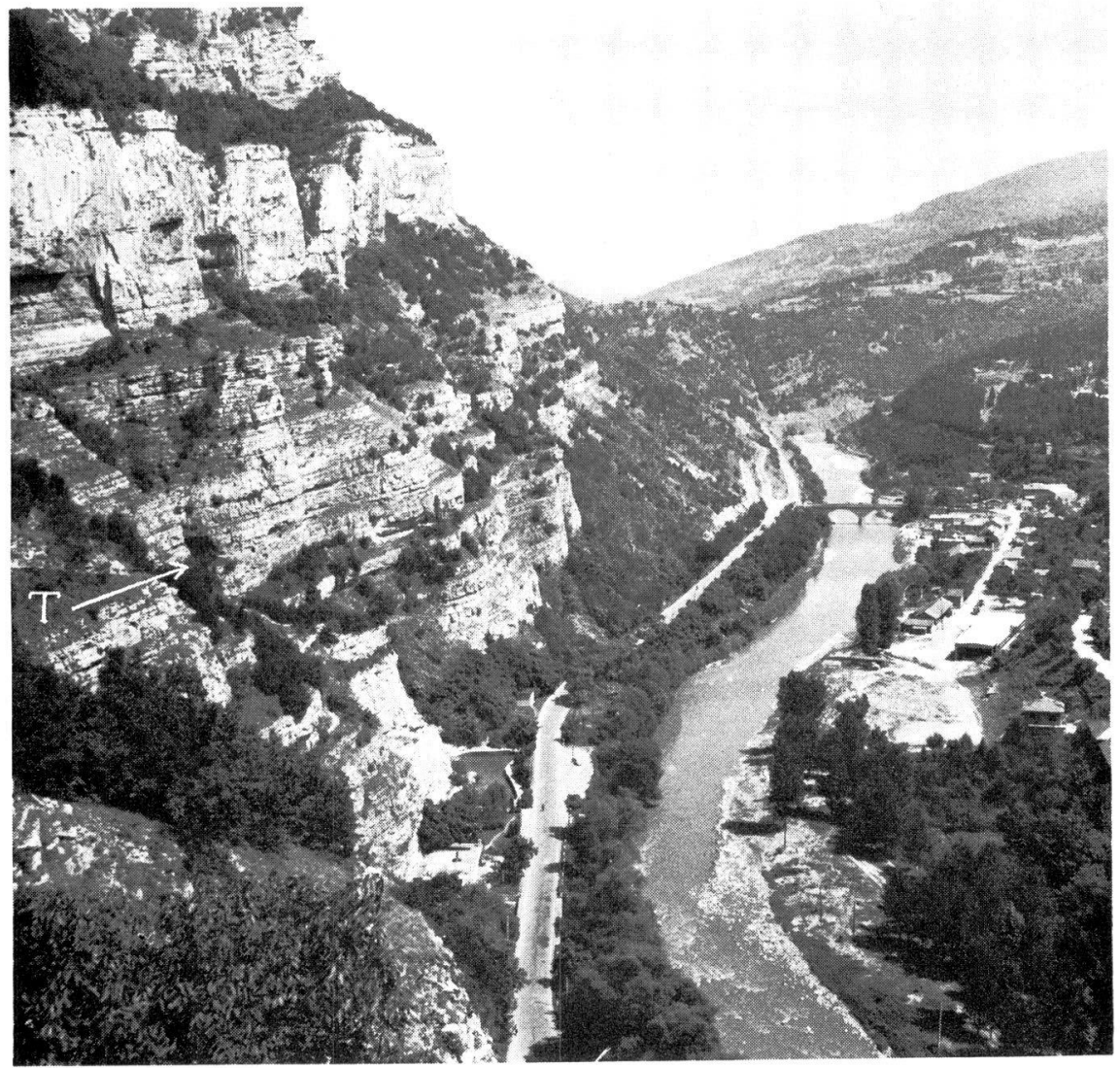

Fig. 1. The Isker Valley in the Stara Planina Mts. - Lakatnik. Left limestone massif with openings of many visited caves. T - Temnata Dupka Cave.

* Natural History Division, Museum in Czestochowa, Czestochowa, Ratusz, Poland. 
Unfortunately the niche of the Lepidoptera, in particular that of the $\mathrm{Mi}$ cro-Moths (Microlepidoptera), in the cavernicolous habitat is still little known in many European caves. Only the caves of Rumania are well known in this respect; from this country are listed 30 species of cave-inhabiting Lepidoptera (Capuse \& Georgescu 1962-1963; Dumitrescu \& colab. 1958, 1967; Georgescu 1962, 1964; Negrea \& Negrea 1968); 16 species are reported from Bulgaria (Guéorguiev \& Beron 1962), and about 70 in the World. But of this number some species occur more frequently and regularly in caves.

The material for this work was collected by the author, in great part, in some Bulgarian caves of the Lakatnik region in the Stara Planina Mountains(Fig. 1) during a botanical and zoological excursion organized in 1960 year by the Students' Association of Naturalists of the Jagiellonian University as well as during his stay here in the year 1970. At the time of my visit in Bulgaria of 4 specimens of Microlepidoptera taken by Mr. P. Beron in Bulgarian caves were given to me for determination by Mr. V. Guéorguiev from the Zoological Institut and Museum of the Bulgarian Academy of Sciences in Sofia. This material is included in this paper also.

\section{EXAMINED MATERIAL AND LOCALITIES}

A c role piida e

Digitivalva (= Acrolepia) granitella $(\mathrm{Tr}$.

Temnata Dupka Cave in Lakatnik 18 VIII 1960 30 $0^{\circ}$; 14-16 VIII 1970 2400, $229 \%$ leg. author.

This species (? ) was mentioned from caves in Bulgaria: by Tuleskov (1930) from the Baco Kiro Cave near Drjanovski Monastir in the Stara Planina Mts. and the Raziska Cave in Lakatnik 19 X 1939 2ex leg. B. Pittioni (Guèorguiev \& Beron 1962).

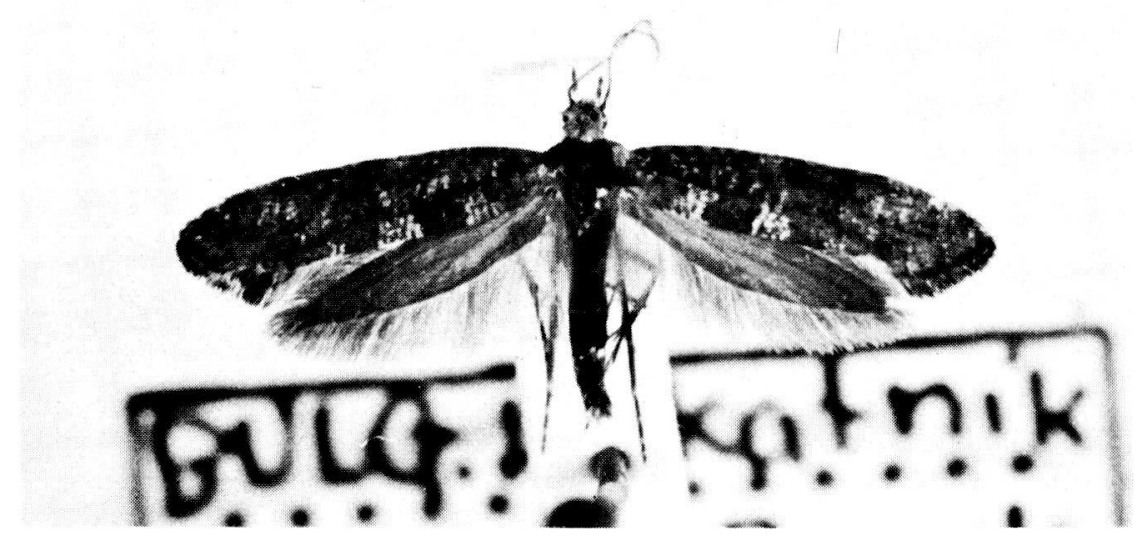

Fig. 2. Imago of $D$. pulicariae (Klim.) (length of the fore wing $-6.5 \mathrm{~mm}$ ) 


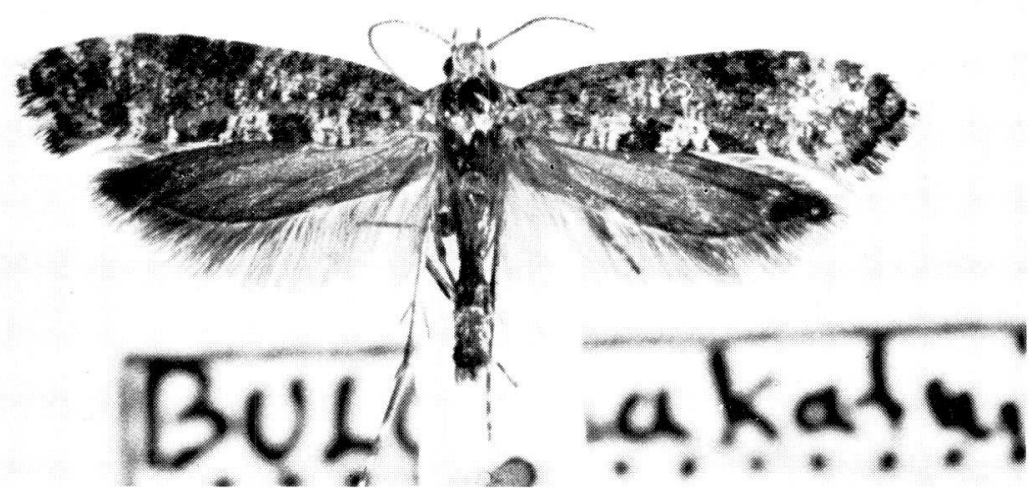

Fig. 3. Imago of D. granitella (Tr.) (Length of the fore wing $7 \mathrm{~mm}$ ).

Moreover, this species (?) has been recorded from caves in Algiers, South Europe to Belgium, South Germany and Rumania (Wolf 1934-1938 and others). But for a certainty it was found in caves of Switzerland (Strinati 1966) and Rumania (Negrea \& Negrea 1968 and others).

\section{D. pulicariae (Klim.)}

Kozarskata Cave in Lakatnik 23 VII $196030^{\circ}, 19$ leg. P. Beron; Temnata Dupka

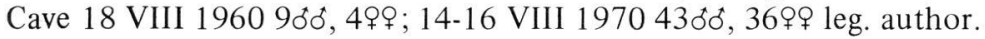

It is a new element in the cave-fauna and fauna of Bulgaria. The species was mentioned as numerous in the caves of Rumania (Capuse \& Georgescu 1962) and an artificial gallery in Belgium (Delhez \& Houssa 1969).

The imago of $D$. pulicariae (Klim.) is rather similar in design and length of the wings to D. granitella (Tr.) (Fig. 2 and 3) but differs distinctly in the genital armature (Fig. 4 and 5)* According to Klimesch (1956) and Gaedike (1970, 1970a) who revised the European species of the genus Acrolepia Curtis; D. pulicariae (Klim.) is widely distributed from south, central and west Europe to Scandinavia, Germany and Czechoslovakia, as well as in Turkey. D. granitella (Tr.) has a narrow range limited to Central Europe (Fig. 6). These species were not recognized as distinct in 1956 (Klimesch 1956), consequently it is possible, that previous cave records of $D$. granitella ( $\mathrm{Tr}$.) apply to $D$. pulicariae (Klim.) or to other species of this group. This problem is one of the most interesting problems for further study.

I found only one locality in which both species occurred together. I have looked in many shorter and longer caves in the Isker Valley near Lakatnik (Fig. 1) but in all of them found only Triphosa sabaudiata Dup. They formed great homotypical compact aggregations by day and partly at night, a large number of them in copula.

* For detailed description see Klimesch (1956) and Gaedike (1970, 1970a). In key of Gaedike (1970a) fig. 6 on color plate shown is D. granitella ( $\mathrm{Tr}$.) and not D. perlepidella (Stain.) as was erroneously given before. 

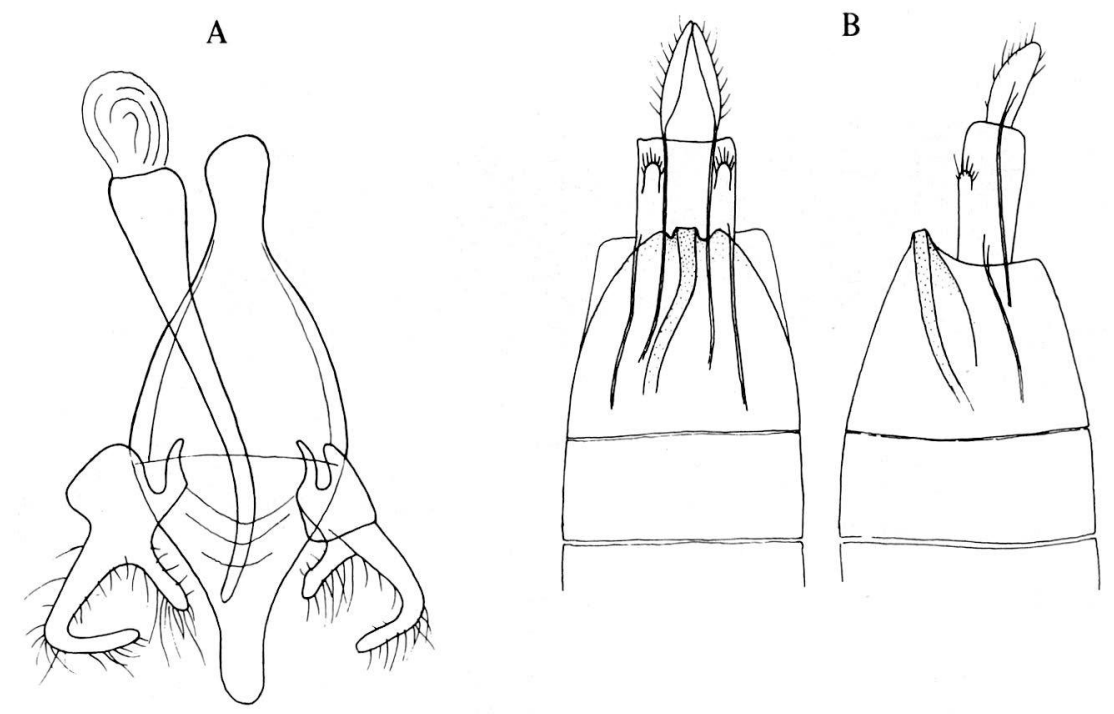

Fig. 4. Genital armatures of D. pulicariae (Klim.) A - male B - female

A

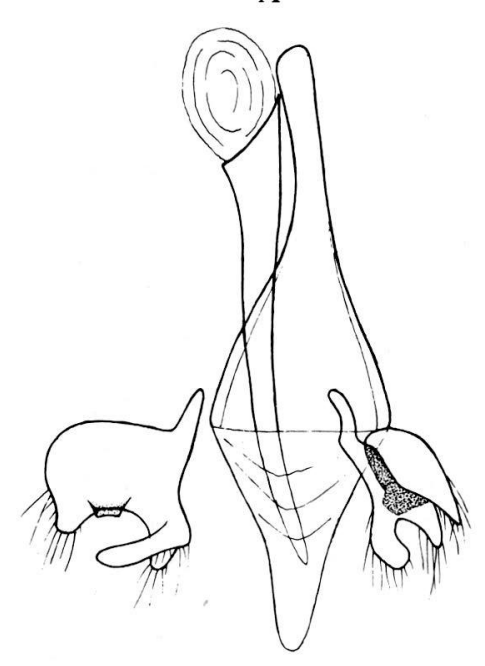

B

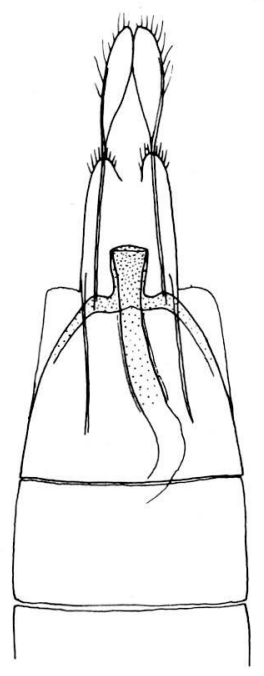

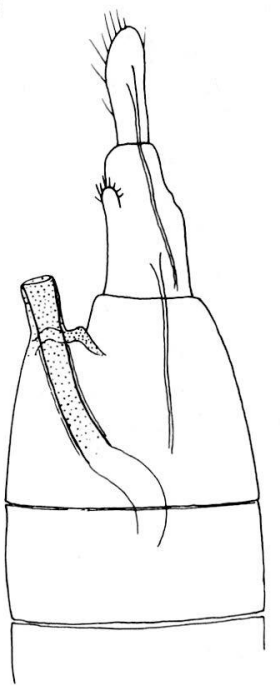

Fig. 5. Genital armatures of D. granitella $(\mathrm{Tr}$.)

A - male

B - female 


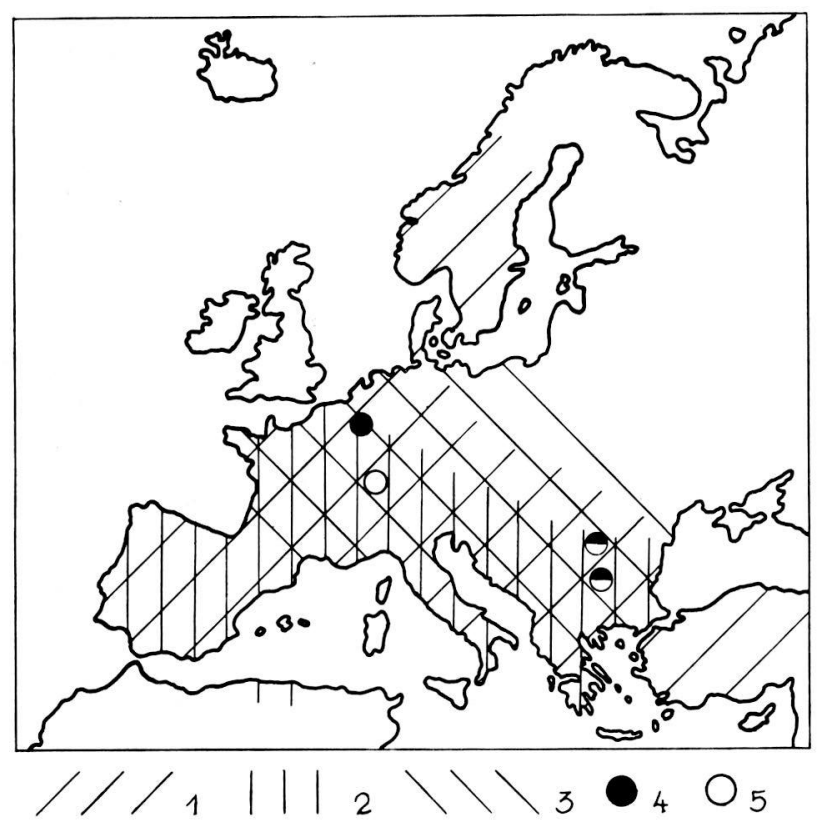

Fig. 6. Distribution of D. pulicariae (Klim.) and D. granitella (Tr.).

1 - distribution of $D$. pulicariae (Klim.)

2 - area of cave records of $D$. granitella (Tr.) (?) according to old literature

3 - distribution of Digranitella (Tr.)

4 - cave localities of $D$. pulicariae (Klim.) lately revised

5 - cave localities of $D$. granitella (Tr.) lately revised

In the Temnata Dupka Cave(Fig. 7) D. pulicariae (Klim.) and D. granitella (Tr.) were observed in some communities with numerous individuals sitting in small niches and cavities up to $150 \mathrm{~m}$ from the entrance in damper places forming "Digitivalva zones" (Fig. 8). Along with these Microlepidoptera I found as singletons specimens of Micropterna nycterobia Mc. L., Limonia nubeculosa (Meig.), Culex sp. and various Diptera Great numbers of individuals, were also observed at night. The communities appeared to be heterotypical (bitypical), loose, only partly compact, aggregations with $D$. pulicariae (Klim.) dominant about 2:1 in relation to second species. It is a very interesting fact that in the Banat Cave in Rumania similar results were obtained (Negrea \& Negrea 1968) whereas in the caves of Oltenia only $D$. pulicariae (Klim.) was noted (Capuse \& Georgescu 1962; Motas, Decou \& Burghele 1967). It was observed in Rumanian caves all year ( 2 generations, 1 hibernating). In this respect, perhaps, D. pulicariae (Klim.) along with $D$. granitella $(\mathrm{Tr}$.) is one of the typical Microlepidoptera components of the parietal associations, at least in several caves of the Balkan peninsula. Thus the common Microlepidoptera of these caves include two species, not only $D$. granitella $(\mathrm{Tr}$.), as biospeleologists have previously concluded in accordance with the older data (Vandel 1965). These 


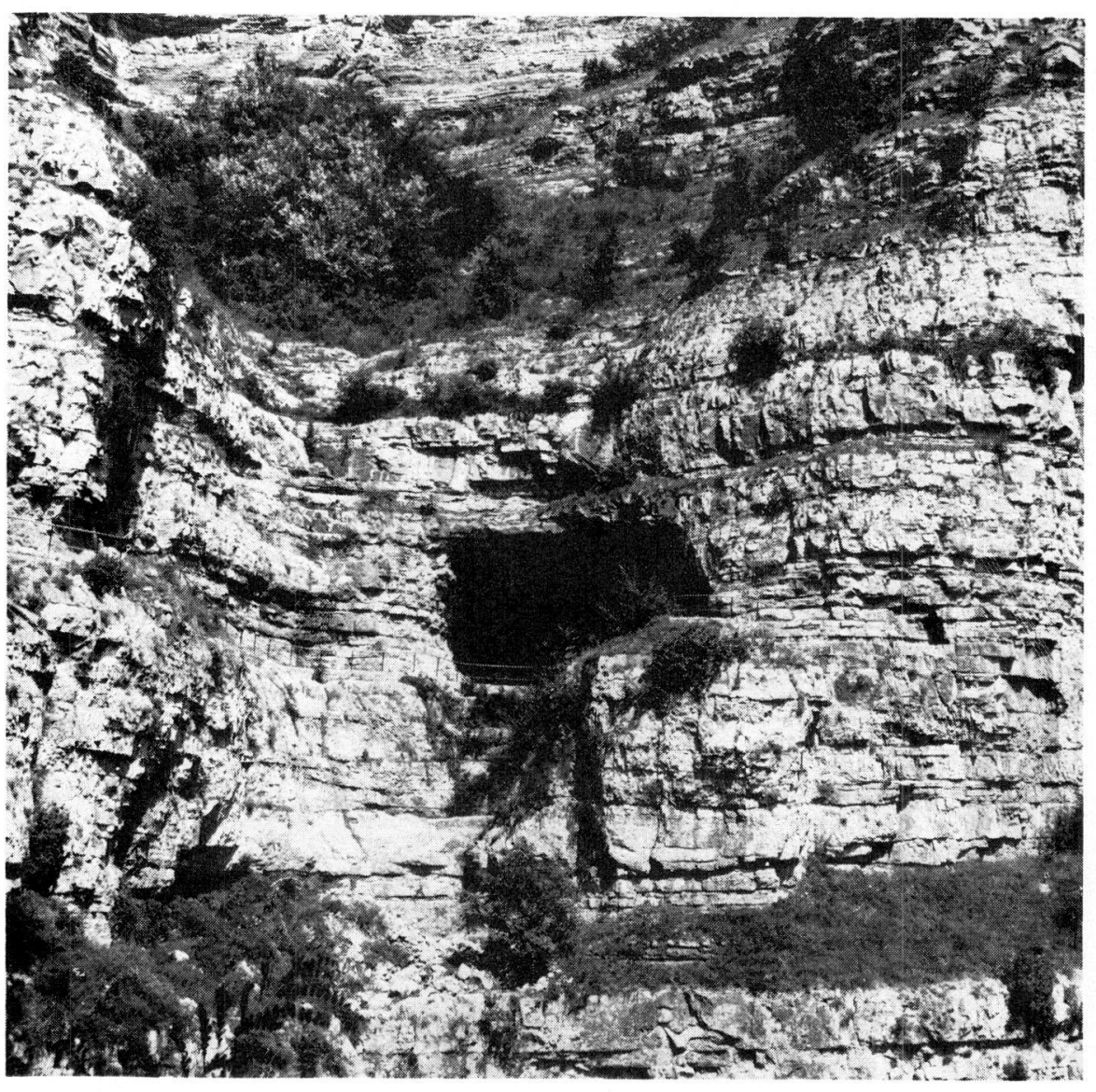

Fig. 7. Opening of the Temnata Dupka Cave.

species are phytophagous (leafmining in larval stage) and represent subtroglophile elements in parietal associations in summer and winter. In the Temnata Dupka Cave many specimens of the both species were transported by subterranean streamlets to the "troglobite zone" in the deeper part of the cave (Fig. 8), in which I observed, e.g., some blind isopods Bureschia bulgarica Verh.) sitting on walls.

Noctuida e

Autophila limbata Stgr.

Temnata Dupka Cave 18 VIII 1960 2qo, 19 VIII 1960 3qक, 14 VIII 1970 1q; Raziska Cave 19 VIII 196019 leg. author. 


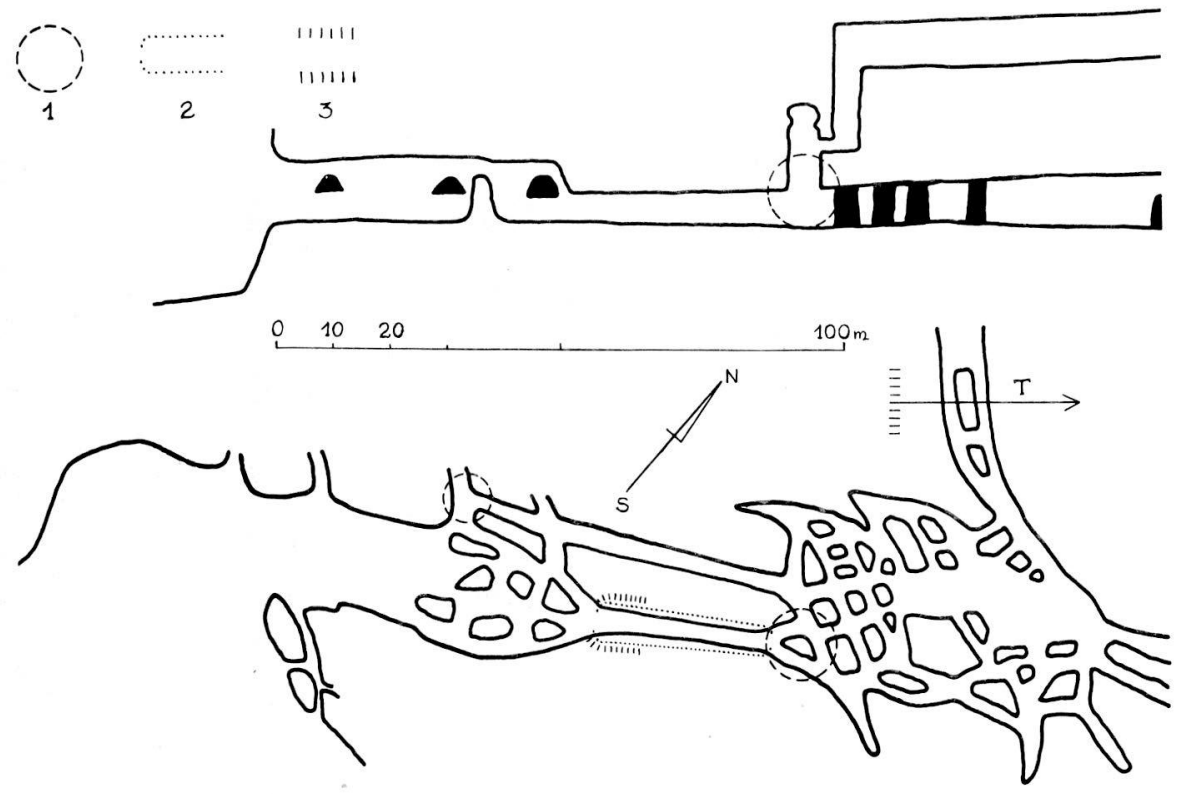

Fig. 8. Entrance parts of the Temnata Dupka Cave (according to Petrov, 1936).

1 - "Digitivalva zones"

2 - spacing of $T$. sabaudiata Dup.

3 - spacing of $A$. limbata Stgr.

T- "troglobite zone"

Many specimens, but singletons were observed to about $10 \mathrm{~m}$ depth in the day only. A new element in cave-fauna and fauna of Bulgaria (Fig. 9).

Species mentioned from cave in Rumania; one female (Dumitrescu, Orghidan \& Tanasachi 1958). Allied species A. bang-baasi Bour. was found in caves of Afghanistan (Lindberg 1963).

\section{ACKNOWLEDGMENTS}

The excursion to Bulgaria in 1960 was patronized and received all possible assistance from Prof. Dr. A. Valkanov (Sofia) to whom the author expresses his gratitude. He also wishes to thank Dr. M. Kuc (Kraków, now Ottawa), scientific chief of the excursion, for friendly, valuable remarks and collaboration, $\mathrm{Mr}$. V. Guéorguiev (Sofia) for his help and material, Dr. W. Mikolajczyk (Warszawa) for determination of Limoniidae and Culicidae as well as Mgr. B. Szczesny (Krakow) for determination of Trichoptera.

The author is also especially thankful to Prof. Dr. R. Husson (Dijon) and Dr. T.C. Barr (Lexington, USA) for editorial assistance. 


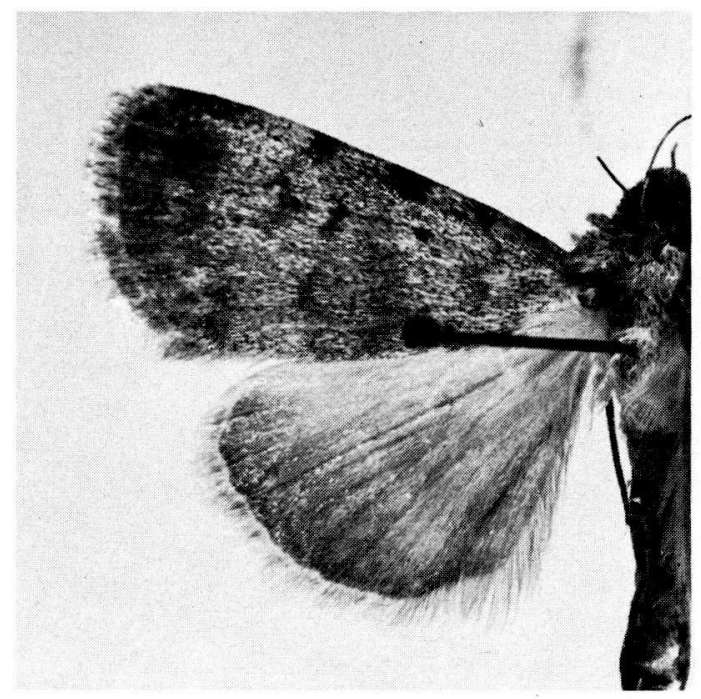

Fig. 9. Imago of $A$. limbata Stgr. (length of the fore wing $-16.5 \mathrm{~mm}$ ).

\section{SUMMARY}

This paper is a report on Lepidoptera collected in 1960 and 1970 in some caves of the Lakatnik region in the Stara Planina Mts. (Bulgaria). The following species were found: Digitivalva granitella (Tr.), D. pulicariae (Klim.), Triphosa sabaudiata Dup. and Autophila limbata Stgr. Two species, D. pulicariae (Klim.) and A. limbata Stgr. are new for the cave-fauna and fauna of Bulgaria.

\section{ZUSAMMENFASSUNG}

Während des Jahres 1960 und 1970 wurden im Gebirge Stara Planina (Bulgarien) in einigen Höhlen bei Lakatnik Lepidoptera gesammelt. In der vorliegenden Arbeit werden die Resultate dieser Sammlungen dargelegt. In Höhlen wurden folgende Lepidopterenarten gefunden: Digitivalva granitella (Tr.), D. pulicariae (Klim.), Triphosa sabaudiata Dup. und Autophila limbata Stgr. Die zwei Arten D. pulicariae (Klim.) und $A$. limbata Stgr. sind für die Höhlenfauna Bulgariens und die Fauna Bulgariens neu. 


\section{REFERENCES}

CAPUSE, I., GEORGESCU, M., 1962 - Acrolepia pulicariae Klim. (Acrolepidae, Lep.) un nouvel élément troglophile dans les grottes de la R.P. Roumaine. Bull. Soc. Ent. Mulhouse, sept.-oct.: 75-78.

1962-1963 - Contributii la studiul lepidopterelor cavernicole. Lucr. Inst. Speol. "E. Racovita", I-II, 495-502.

DUMITRESCU, M., ORGHIDAN, T., TANASACHI, J., 1958 - Pestera de la Gura Dobrogei. Ann. Com. Geol., XXXI, 461-482.

DUMITRESCU, M. \& COLAB., 1967 - Contributii la studiul pesterilor din regiunea Hunedoara. Lucr. Inst. Speol. "E. Racovita”, VI, 9-88.

DELHEZ, F., HOUSSA, M., 1969 - L'Araine de Richeronfontaine à Liège. Etude écologique de la faune cavernicole d'un réseau souterrain artificiel. Les Naturalistes Belges, 50, 4, 194-212.

GAEDIKE, R., 1970 - Revision der paläarktischen Acrolepiidae. Ent. Abh. Mus. Tierk. Dresden, 38, 1, 1-54.

1970a- Beiträge zur Insekten-Fauna der DDR: Lepidoptera - Acrolepiidae. Beitr. Ent., 20, 3/4, 209-222.

GEORGESCU, M., 1962 - Haplotinea ditella Pce. et Diak. (Tineidae-Lepidoptera) element nou pentru fauna R.P.R. Com. Acad. R.P.R., XII, 11, 1201-1203.

1964 - Contribution à l'étude des Microlépidoptères (Tineidae) des grottes de Roumanie. Ann. Speol., XIX, 3, 587-597.

GRAHAM, R.E., 1968 - Spatial biometrica of subterranean demes of Triphosa haesitata (Lepidoptera: Geometridae). Caves and Karst, 10, 3, 21-29.

1968a - The Twilight Moth, Triphosa haesitata (Lepidoptera: Geometridae) from California and Nevada caves. Ibidem, 5, 41-48.

GUEORGUIEV, V., BERON, P., 1962 - Essai sur la faune cavernicole de Bulgarie. Ann. Speol., XVII, 2 et $3,285-441$.

KLIMESCH, J., 1956 - Die Arten der Acrolepia granitella Tr.-Gruppe Zeit. Wien. ent. Ges., 41, 129-144.

KOWALSKI, W., 1965 - Ethological and ecological observations on Lepidoptera in their subterranean hibernating places in the vicinity of Cracow. Zesz. Nauk. Uniw. Jagtell. Prace Zool., CIII, 9: 97-157.

LINDBERG, K., 1963 - Notes sur les grotte d'Afghanistan et aperçu de leur faune. Actes Deux Congr. Inter. Spéléol., II, 109-143.

MOTAS, C., DECOU, V., BUYGHELE, A., 1967 - Sur l'association pariétale des grottes d'Olténie (Roumanie). Ann. Speol., XXII, 3, 475-522.

NEGREA, S., NEGREA, A., 1968 - Contributie le studiul asociatiei parietale a pesterilor din Banat. Lucr. Inst. Speol. "E. Racovita”, VII, 79-148.

PETROV', P., 1936 - Pesterata “Temnata Dupka” pri gara Lakatnik'. Mitt. Bulg. Spel. Ges., I: 53-74.

STRINATI, P., 1966 - Faune cavernicole de la Suisse. Ed. CNRS.

TULESKOV, K., 1930 - Erster Beitrag zur Lepidopterenfauna der Stadt Tirnovo und ihrer Umgebung. Mitt. Bulg. ent. Ges., V, 125-162.

WOLF, B., 1934-1938 - Animalium Cavernarum Catalogus, III. Gravenhage.

VANDEL, A., 1965 - Biospeleology. The Biology of Cavernicolous Animals. Pergamon Press. 